\title{
Simulation of Residue Hydrodesulfurization Reaction Based on Catalyst Deactivation Model
}

\author{
Shoji Kodama*1), Haruhiko Nitta*2), Tohru Takatsuka*1) and Tohru Yokoyama*1)
}

A model was proposed to describe deactivation of hydrodesulfurization catalysts for residues. In this model, demetallization interacts with coking reaction on a catalyst, and these two reactions cause both active site poisoning and pore plugging. According to the pore diffusion theory, the reduction of active surface area and effective diffusivity affects the catalyst deactivation. A simulator for residue hydrodesulfurization was developed on the basis of this deactivation model.

The parameters of this simulator were obtained from residue hydrodesulfurization experiments, and they were found to be dependent on the properties of the catalyst and the feedstock. Simulation by use of the above specified parameters enabled to predict the actual operations of bench scale fixed-bed and moving-bed reactors.

\section{Introduction}

The life of hydrodesulfurization (HDS) catalysts for residues is very much dependent on both coke deposition and metal accumulation. An attempt was made to describe the HDS process by computer simulation in consideration of reaction kinetics and fouling processes.

Although commercialized residue HDS processes have either a fixed bed or an ebullated bed of catalyst, a moving catalyst bed system would be a promising alternative. We have developed a simulation model of the HDS reaction which is applicable to both fixed-bed and moving-bed systems.

An extensive study of residue HDS kinetics has been made by many researchers, and the overall rate of desulfurization is expressed as secondorder with respect to the sulfur content in many cases $^{1}$. Second-order kinetics, however, cannot be applied to deep desulfurization ${ }^{1), 3)}$. It is also reported that the reaction behavior was well represented by assuming the following model: the apparent reaction order was determined by both the sulfur content and the rate constants of reactive/nonreactive sulfur compounds ${ }^{4), 7)}$. The mass transfer effect in a porous catalyst is also Received Sep. 10, 1979.

*1) Research \& Development Center, Chiyoda Chemical Engineering \& Construction Co., Ltd. (3-13 Moriya-cho, Kanagawa-ku, Yokohama 221)

*2) Petroleum Refining Engineering Department, Chiyoda Chemical Engineering \& Construction Co., Ltd. (1580 Tsurumi-cho, Tsurumi-ku, Yokohama 230) an active research area ${ }^{5), 6)}$. Spray et al. ${ }^{8)}$ have studied the relationship between molecular diameter and diffusion coefficient of asphaltene in a petroleum feedstock.

As far as the process of catalyst deactivation in general is concerned, various deactivation models have been described ${ }^{12), 16), 17), ~ s i n c e ~ W h e e l e r ~}{ }^{10), 11)}$ proposed a uniform poisoning and a poremouth poisoning model. For the contamination mechanism of residue HDS, Newson ${ }^{13)}$ proposed a poreplugging model, and he attempted to estimate the catalyst cycle length in a trickle-bed HDS reactor. Parkin et al. ${ }^{14}$ ) proposed a more generalized expression, and showed that analog computer simulation was a useful tool in the design of an HDS reactor.

National Chemical Laboratory for Industry, Japan, has proposed a new type of HDS process or the Moving-bed Hydrodesulfurization (MDS) Process. The flow scheme of this MDS Process is as follows ${ }^{15), 19)}$ : the liquid feed and hydrogen-rich gas introduced into the reactor from the bottom of the reactor flow upward. The used catalyst is withdrawn from the reactor bottom, and fresh catalyst is fed from the top. Although the catalyst is added and withdrawn during operation both in the MDS Process and the ebullatedbed process, the major difference between the two processes is that only the most deactivated catalyst is withdrawn in the MDS Process; thus, reducing catalyst consumption.

The process of catalyst deactivation in an MDS reactor is compared with that in a fixed-bed system 
Table 1 Changes in Quantities of Coke and Vanadium on HDS Catalysts

\begin{tabular}{|c|c|c|c|c|c|}
\hline Catalyst & \multicolumn{2}{|c|}{$\mathrm{F}$} & G & $\mathrm{H}$ & I \\
\hline $\begin{array}{l}\text { Properties of Fresh Cat. } \\
\text { Pore Volume, } \mathrm{cm}^{3} / \mathrm{g} \\
\text { Surface Area, } \mathrm{m}^{2} / \mathrm{g} \\
\text { Size of Extrudate, } \mathrm{mm} \\
\text { Packed Density, } \mathrm{g} / \mathrm{cm}^{3}\end{array}$ & \multicolumn{2}{|c|}{$\begin{array}{l}0.47 \\
294 \\
1.5 \times 5 \\
0.71\end{array}$} & $\begin{array}{l}0.56 \\
161 \\
0.9 \times 4 \\
0.65\end{array}$ & $\begin{array}{l}0.66 \\
198 \\
0.9 \times 5 \\
0.59\end{array}$ & $\begin{array}{l}0.58 \\
174 \\
0.8 \times 5 \\
0.64\end{array}$ \\
\hline $\begin{array}{l}\text { HDS Test with Fresh Cat. } \\
\text { Feedstock } \\
\text { Pressure, } \mathrm{kg} / \mathrm{cm}^{2} \cdot \mathrm{G} \\
\text { Temperature, }{ }^{\circ} \mathrm{C} \\
\text { LHSV, } \mathrm{hr}^{-1} \\
\mathrm{H}_{2} / \text { Oil, N1/l } \\
\text { Sulfur in Product, wt } \% \\
\text { Process Time, hr }\end{array}$ & $\begin{array}{c}\text { Khafji A.R. } \\
130 \\
385 \\
0.3 \\
900 \\
0.4-0.6 \\
650\end{array}$ & $\begin{array}{c}\text { Khafji A.R. } \\
130 \\
395 \\
0.3 \\
1,000 \\
0.2-0.4 \\
540\end{array}$ & $\begin{array}{c}\text { Kuwait A.R. } \\
145 \\
339-402 \\
0.9 \\
800 \\
1.0 \\
4,000\end{array}$ & $\begin{array}{c}\text { Kuwait A.R. } \\
140 \\
360-410 \\
1.0 \\
850 \\
1.0 \\
6,000\end{array}$ & $\begin{array}{c}\text { Khafji A.R. } \\
130 \\
345-410 \\
2.0 \\
1,200 \\
2.5 \\
2,700\end{array}$ \\
\hline $\begin{array}{l}\text { Deposit on Used Cat. } \\
\text { Vanadium, wt } \% \\
\text { Carbon, wt } \% \\
\text { Position in Cat. Bed }\end{array}$ & $\begin{array}{r}4.7 \\
7.3 \\
\text { Inlet }\end{array}$ & $\begin{array}{r}4.4 \\
9.0 \\
\text { Inlet }\end{array}$ & $\begin{array}{r}22.8 \\
27.9 \\
\text { Inlet }\end{array}$ & $\begin{array}{r}42.2 \\
7.3 \\
\text { Inlet }\end{array}$ & $\begin{array}{l}28.2 \\
15.8 \\
\text { Middle }\end{array}$ \\
\hline $\begin{array}{l}\text { HDS Test with Used Cat. } \\
\text { Feedstock } \\
\text { Pressure, } \mathrm{kg} / \mathrm{cm}^{2} \cdot \mathrm{G} \\
\text { Temperature, }{ }^{\circ} \mathrm{C} \\
\text { LHSV, } \mathrm{hr}^{-1} \\
\mathrm{H}_{2} / \text { Oil, } \mathrm{N} 1 / l \\
\text { Process Time, hr }\end{array}$ & \multicolumn{5}{|c|}{$\begin{array}{c}\text { Iranian Heavy A.R.(S-1) } \\
130 \\
385 \\
1.0 \\
1,000 \\
1,800\end{array}$} \\
\hline $\begin{array}{l}\text { Deposit on Used Cat. } \\
\text { Vanadium, wt } \% \\
\text { Carbon, wt } \%\end{array}$ & $\begin{array}{r}14.5 \\
5.6\end{array}$ & $\begin{array}{r}14.9 \\
6.8\end{array}$ & $\begin{array}{l}36.6 \\
10.4\end{array}$ & $\begin{array}{r}42.8 \\
7.8\end{array}$ & $\begin{array}{r}36.0 \\
4.6\end{array}$ \\
\hline
\end{tabular}

as follows: In a fixed-bed system, the decline in catalyst activity is compensated by gradual rise in temperature from the start of a run (SOR) to the end of the run (EOR), where metal deposition plays a major role in deactivation. On the other hand, the catalyst activity in an MDS reactor is maintained by partial replacement of the deactivated catalyst by fresh catalyst. Operation is normally carried out at a constant temperature higher than the SOR of the corresponding design of a fixed bed system. Thus, the catalyst, especially fresh one in an MDS reactor, is likely to be deactivated by deposition of both metal and coke accelerated at higher temperatures.

Since it is not possible to simulate the catalyst deactivation of the MDS Process by the above mentioned model of Parkin et al.*, it is necessary to develop a deactivation model applicable to MDS Process simulation.

\section{Simulation Model}

\subsection{HDS Kinetics}

The residue HDS kinetic model can be determined on the basis of previously known ex-

* Deactivation model by Parkin is based on the following assumptions : i) coke deposition is limited to the SOR period, ii) the amount of coke on the catalyst is not affected by temperature, iii) the same amount of coke deposits on the catalyst throughout the reactor. perimental results. In addition to the main desulfurization reaction, the model includes demetallization and coking reaction which take place on HDS catalysts. However, the residue contains vanadium and nickel as metal contaminants both of which deactivate the catalyst. For convenience in this calculation, demetallization is represented by vanadium removal and the effect of nickel on deactivation is included in the parameters as will be mentioned later.

To describe the rate equations of desulfurization and vanadium removal, both rates are expressed by second order reactions, and to be proportional to the hydrogen concentration in the liquid phase ${ }^{2)}$. Therefore, the mass transfer in a porous catalyst generally affects the above two reactions, and the rate equations of this HDS kinetic model can be summarized as follows for desulfurization and vanadium removal, respectively:

$$
\begin{aligned}
& r_{\mathrm{s}}=\rho \text { cat } \cdot A_{\mathrm{os}} \cdot E f_{\mathrm{s}} \cdot k_{\mathrm{s}} \cdot C_{\mathrm{h}} \cdot C_{\mathrm{s}}{ }^{2} \\
& r_{\mathrm{v}}=\rho \text { cat } \cdot A_{\mathrm{ov}} \cdot E f_{\mathrm{v}} \cdot k_{\mathrm{v}} \cdot C_{\mathrm{h}} \cdot C_{\mathrm{v}}{ }^{2}
\end{aligned}
$$

where $E f$ is the effectiveness factor and $k$ is the intrinsic rate constant.

Beuther et al. ${ }^{1}$ ) and Inoguchi et al. ${ }^{9}$ reported that the coke deposit reached the equilibrium level in the early period of a run, and that catalyst deactivation in an MDS reactor could not be simulated with Parkin's model. 
So it was necessary to measure the change in coke deposit for an extended period of time. The purpose of the experiments shown in Table 1 was to investigate this change. The HDS experiment of 1,800 hours at certain fixed conditions was conducted using five catalysts of four types, which had already been used in the HDS tests for 500 to 6,000 hours, and the changes in the coke and vanadium deposits were measured before and after the run. Analytical data of catalysts and experimental conditions are shown in Table 1.

The results obtained for each catalyst were remarkable: the vanadium deposit increased and the coke deposit never increased but decreased sharply. Thus, it is proposed that i) coke deposition may be reversible because the deposited coke is able to decrease, ii) and vanadium may expel the coke which has previously been deposited.

Based on these two assumptions, the coke deposition model for the MDS Process can be expressed by Eq. (3).

$$
r_{\mathrm{c}}=\rho \mathrm{cat} \cdot A_{\mathrm{oc}} \cdot k_{\mathrm{c} 1}-\rho \mathrm{cat} \cdot A_{\mathrm{o}} \cdot k_{\mathrm{c} 2} \cdot C_{\mathrm{h}} \cdot q_{\mathrm{c}}
$$

where $q_{\mathrm{c}}$ is the amount of coke on the catalyst. Eq. (3) indicates that reduction of an active surface area $A_{\mathrm{oc}}$ gives a negative value to $r_{\mathrm{c}}$; thus, causing a decrease in coke content on the catalyst. Furthermore, the latter assumption, ii), defines $A_{\mathrm{oc}}$ expressed by Eq. (14).

The temperature dependency of all rate constants, $k_{\mathrm{s}}, k_{\mathrm{v}}, k_{\mathrm{c} 1}$ and $k_{\mathrm{c} 2}$ is represented by typical Arrhenius behavior. Hydrogen concentration in the residue is affected by both reaction pressure and temperature, and the solubility of hydrogen is given by

$$
\begin{aligned}
C_{\mathrm{h}}= & \left(8.91 \times 10^{-6}\right) \cdot P+\left(4.16 \times 10^{-6}\right) . \\
& (T-273)-1.40 \times 10^{-3}
\end{aligned}
$$

for $50<P<180, \quad 573<T<733$

\subsection{Gatalyst Deactivation}

Metal and coke accumulate on the catalyst pellets with time, and catalyst activity decreases. In our catalyst deactivation model, the cause for deactivation is postulated to be the deposition of vanadium and coke. The quantities of vanadium and coke accumulated are given by Eqs. (2) and (3), respectively:

$$
\begin{aligned}
& Q_{\mathrm{V}}=100 \int_{0}^{\theta} r_{\mathrm{v}} d \theta / \rho \mathrm{cat} \\
& Q_{\mathrm{c}}=100 \int_{0}^{\theta} r_{\mathrm{c}} d \theta / \rho \mathrm{cat}
\end{aligned}
$$

These two equations can be rearranged in dimensionless forms as follows:

$$
\psi_{\mathrm{v}}=Q_{\mathrm{v}} /\left(100 \cdot P_{\mathrm{v}} \cdot \rho_{\mathrm{v}}\right)
$$

$$
\phi_{\mathrm{c}}=Q_{\mathrm{c}} /\left(100 \cdot P_{\mathrm{v}} \cdot \rho_{\mathrm{c}}\right)
$$

where $P_{\mathrm{v}}$ is the catalyst pore volume, and $\rho_{\mathrm{v}}$ and $\rho_{\mathrm{c}}$ are the densities of vanadium and coke, respectively. $\phi_{\mathrm{v}}$ and $\psi_{\mathrm{c}}$ are the volumes of contaminants per unit pore volume.

The decrease in the active surface area causes a decline of activity in hydrodesulfurization and in vanadium removal. Assuming the thickness of the contaminants in a cylindrical pore to be constant, the relationship between surface area and pore volume is expressed as:

$$
\frac{A_{\mathrm{o}^{\prime}}}{A_{\mathrm{o}}}=\left(\frac{P_{\mathrm{v}^{\prime}}{ }^{\prime}}{P_{\mathrm{v}}}\right)^{1 / 2}
$$

where $A_{\mathrm{o}}$ is the surface area of a fresh catalyst, and $A_{\mathrm{o}}{ }^{\prime}$ and $P_{\mathrm{v}}{ }^{\prime}$ are the remaining surface area and pore volume under use, respectively. According to the definition of dimensionless contaminants,

$$
\frac{P_{\mathrm{v}}{ }^{\prime}}{P_{\mathrm{v}}}=1-\psi_{\mathrm{v}}-\psi_{\mathrm{c}}
$$

If the quantities of the contaminants are small, i.e. $\phi_{\mathrm{v}}+\psi_{\mathrm{c}} \ll 1$, the remaining surface area is given by the following equation by combining Eqs. (9) and (10),

$$
A_{\mathrm{o}}=A_{\mathrm{o}}{ }^{\prime} \cdot\left(1-\frac{1}{2} \psi_{\mathrm{v}}-\frac{1}{2} \psi_{\mathrm{c}}\right)
$$

If the active surface area is considered to be proportional to the catalyst surface area, the reduced active surface area for both reactions can conveniently be expressed by the following equations:

$$
\begin{aligned}
& A_{\mathrm{os}}=A_{\mathrm{o}} \cdot\left(1-\alpha_{\mathrm{v}} \cdot \psi_{\mathrm{v}}-\alpha_{\mathrm{c}} \cdot \psi_{\mathrm{c}}\right) \\
& A_{\mathrm{ov}}=A_{\mathrm{o}} \cdot\left(1-\beta_{\mathrm{v}} \cdot \psi_{\mathrm{v}}-\beta_{\mathrm{c}} \cdot \psi_{\mathrm{c}}\right)
\end{aligned}
$$

where $\alpha_{\mathrm{v}}, \alpha_{\mathrm{c}}, \beta_{\mathrm{v}}$ and $\beta_{\mathrm{c}}$ are the parameters which include the effect of nickel deposition, $\mathrm{C} / \mathrm{H}$ ratio of coke etc. As the deposit of vanadium occupies the surface area for coke formation, the remaining active surface area for coke formation is given by

$$
A_{\mathrm{oc}}=A_{\mathrm{o}} \cdot\left(1-\gamma_{\mathrm{v}} \cdot \psi_{\mathrm{v}}\right)
$$

Another deactivation factor is the deposited substances that hinder intraparticle diffusion of reactants. The vanadium deposition is supposed to have a significant effect on the effective diffusivity of the porous medium; therefore, the decline of effective diffusivity is expressed by the following equations for sulfur and vanadium, respectively:

$$
\begin{aligned}
& D_{\mathrm{s}}=D_{\mathrm{so}} \cdot\left(1-\delta_{\mathrm{v}} \cdot \frac{\phi_{\mathrm{v}}}{\phi_{\max }}\right) \\
& D_{\mathrm{v}}=D_{\mathrm{vo}} \cdot\left(1-\frac{\phi_{\mathrm{v}}}{\phi_{\mathrm{max}}}\right)
\end{aligned}
$$

where $\delta_{\mathrm{v}}$ is the parameter, which adjusts the vanadium deposition so as to have a different effect 
Table 2 Properties of Feedstocks

\begin{tabular}{|c|c|c|c|c|c|c|c|}
\hline & $\begin{array}{c}\text { Khafji } \\
\text { A.R. }\end{array}$ & $\begin{array}{c}\text { Kuwait } \\
\text { A.R. }\end{array}$ & $\begin{array}{c}\text { Iranian } \\
\text { Heavy A.R. } \\
(\mathrm{S}-1)\end{array}$ & $\begin{array}{c}\text { Iranian } \\
\text { Heavy A.R. } \\
(\mathrm{S}-2)\end{array}$ & Heavy V.R. & $\begin{array}{c}\text { Khafji } \\
\text { V.R. }\end{array}$ & $\begin{array}{l}\text { Boscan } \\
\text { Crude }\end{array}$ \\
\hline $\begin{array}{c}\text { Specific Gravity }\left(15 / 4^{\circ} \mathrm{C}\right) \\
\text { Viscosity at } 50^{\circ} \mathrm{C}, \mathrm{cSt} \\
\text { at } 100^{\circ} \mathrm{C}, \mathrm{cSt} \\
\text { Carbon Residue, wt } \% \\
\text { Asphaltene Content, wt } \% \\
\text { Sulfur Content, wt } \% \\
\text { Nitrogen Content, wt } \% \\
\text { Metals, Vanadium, ppm } \\
\text { Nickel, ppm } \\
\text { Sodium, ppm } \\
\text { Iron, ppm }\end{array}$ & $\begin{array}{l}0.9734 \\
617.4 \\
- \\
11.5 \\
5.9 \\
4.09 \\
0.26 \\
74 \\
27 \\
35 \\
2\end{array}$ & $\begin{array}{l}0.9518 \\
186.0 \\
\overline{-} \\
9.1 \\
2.6 \\
3.65 \\
0.22 \\
49 \\
12 \\
2 \\
3\end{array}$ & $\begin{array}{l}0.9624 \\
462.4 \\
\overline{9} \\
9.7 \\
3.7 \\
2.57 \\
0.45 \\
142 \\
54 \\
3 \\
3\end{array}$ & $\begin{array}{l}0.9587 \\
312.9 \\
\overline{9} \\
9.5 \\
2.8 \\
2.62 \\
0.35 \\
120 \\
38 \\
48 \\
14\end{array}$ & $\begin{array}{c}1.0379 \\
2,890 \\
21.6 \\
8.2 \\
3.67 \\
0.76 \\
270 \\
92 \\
4 \\
13\end{array}$ & $\begin{array}{c}1.0389 \\
6,-101 \\
23.8 \\
13.0 \\
5.39 \\
0.47 \\
165 \\
53 \\
4 \\
13\end{array}$ & $\begin{array}{c}0.9978 \\
5,612 \\
200.4 \\
15.9 \\
11.5 \\
5.18 \\
0.59 \\
1,130 \\
106 \\
45 \\
4\end{array}$ \\
\hline
\end{tabular}

on the diffusion of sulfur or vanadium. The effective diffusivity also varies with temperature according to the Arrhenius expression.

\subsection{Effectiveness Factor}

The effectiveness factor used in Eq. (1) or (2) depends on the reactant concentration, which is affected by diffusion in a porous medium. The mass balances of sulfur and vanadium may be respectively written in the case of a spherical catalyst:

$$
\begin{aligned}
& \frac{1}{r} \cdot \frac{d}{d r}\left(r^{2} D_{\mathrm{s}} \cdot \frac{d \rho \mathrm{oil} \cdot C_{\mathrm{s}}}{d r}\right)=\rho \mathrm{cat} \cdot A_{\mathrm{os}} \cdot k_{\mathrm{s}} \cdot C_{\mathrm{h}} \cdot C_{\mathrm{s}}{ }^{2} \\
& \frac{1}{r} \cdot \frac{d}{d r}\left(r^{2} D_{\mathrm{v}} \cdot \frac{d \rho \mathrm{oil} \cdot C_{\mathrm{v}}}{d r}\right)=\rho \mathrm{cat} \cdot A_{\mathrm{ov}} \cdot k_{\mathrm{v}} \cdot C_{\mathrm{h}} \cdot C_{\mathrm{v}}{ }^{2}
\end{aligned}
$$

Hydrogen concentration is postulated to be the same in and out of the catalyst.

Since larger amounts of vanadium deposit on the outer parts of a pellet than at the central part, the effective diffusivity is not constant throughout the pellet. However, in our calculation, we assumed, for convenience, that the effective diffusivity distributed uniformly throughout the pellet.

Eq. (17) or (18) is converted to a differential equation as follows:

$$
\frac{d^{2} \phi}{d \eta^{2}}+\frac{2}{\eta} \cdot \frac{d \phi}{d \eta}=h^{2} \cdot \phi^{2}
$$

where $\phi$ is the dimensionless concentration, and $\eta$ is the dimensionless distance from the pellet center. The Thiele-modulus $h$ is defined by Eq. (20) or (21).

$$
\begin{aligned}
& h_{\mathrm{s}}=r_{\mathrm{o}} \sqrt{\frac{\rho \mathrm{cat} \cdot A_{\mathrm{os}} \cdot k_{\mathrm{s}} \cdot G_{\mathrm{h}} \cdot C_{\mathrm{s}}}{\rho \mathrm{oil} \cdot D_{\mathrm{s}}}} \\
& h_{\mathrm{v}}=r_{\mathrm{o}} \sqrt{\frac{\rho \mathrm{cat} \cdot A_{\mathrm{ov}} \cdot k_{\mathrm{v}} \cdot C_{\mathrm{h}} \cdot C_{\mathrm{v}}}{\rho \mathrm{oil} \cdot D_{\mathrm{v}}}}
\end{aligned}
$$

where $r_{\mathrm{o}}$ is the equivalent pellet diameter, and the boundary conditions are,
Table 3 Physical Properties of HDS Catalysts

\begin{tabular}{c|l|lccc}
\hline Catalyst & Type & $\begin{array}{c}\text { Pore } \\
\text { Volume } \\
\left(\mathrm{cm}^{3} / \mathrm{g}\right)\end{array}$ & $\begin{array}{c}\text { Surface } \\
\text { Area } \\
\left(\mathrm{m}^{2} / \mathrm{g}\right)\end{array}$ & $\begin{array}{c}\text { Equiva- } \\
\text { lent Dia. } \\
(\mathrm{mm})\end{array}$ & $\begin{array}{c}\text { Packed } \\
\text { Density } \\
\left(\mathrm{g} / \mathrm{cm}^{3}\right)\end{array}$ \\
\hline A & Ni-Co-Mo & 0.440 & 280 & 1.16 & 0.740 \\
$\mathrm{~B}$ & Ni-Co-Mo & 0.500 & 180 & 1.41 & 0.650 \\
$\mathrm{G}$ & Ni-Co-Mo & 0.558 & 161 & 1.22 & 0.650 \\
D & Co-Mo & 0.601 & 155 & 1.34 & 0.660 \\
E & Co-Mo & 0.786 & 341 & 1.59 & 0.528 \\
\hline
\end{tabular}

$$
\begin{aligned}
& \frac{d \phi}{d \eta}=0 \quad \text { at } \quad \eta=0 \\
& \phi=1 \quad \text { at } \quad \eta=1
\end{aligned}
$$

The dimensionless differential equation was solved by use of the Thomas method ${ }^{21)}$ and the distribution of concentration along the pellet radius was obtained. Consequently, the relation between the effectiveness factor and the Thiele-modulus was obtained. This relation was programmed in the simulator to shorten the calculation time.

\subsection{Reactor Model}

The material balances of sulfur and vanadium in a plug-flow reactor may be derived as follows:

$$
\begin{aligned}
& U_{1} \frac{d C_{\mathrm{s}}}{d z}+\varepsilon \cdot r_{\mathrm{s}}=0 \\
& U_{1} \frac{d C_{\mathrm{v}}}{d z}+\varepsilon \cdot r_{\mathrm{v}}=0
\end{aligned}
$$

If the temperature gradient in the radial direction is neglected, the heat balance for an adiabatic HDS reactor is represented by the following equation:

$$
\left(U_{1} \cdot C_{\mathrm{p} 1}+U_{\mathrm{g}} \cdot C_{\mathrm{pg}}\right) \frac{d T}{d z}-\left(-\Delta H_{\mathrm{s}}\right) \cdot \varepsilon \cdot r_{\mathrm{s}}=0
$$

where $\left(-\Delta H_{\mathrm{s}}\right)$ is the overall heat of reaction of the HDS reaction process.

\section{Experimental and Parameter Estimation}

\subsection{Experimental}

In this study, the HDS tests were made by use of five catalysts prepared in our laboratory and three petroleum feedstocks in order to determine 


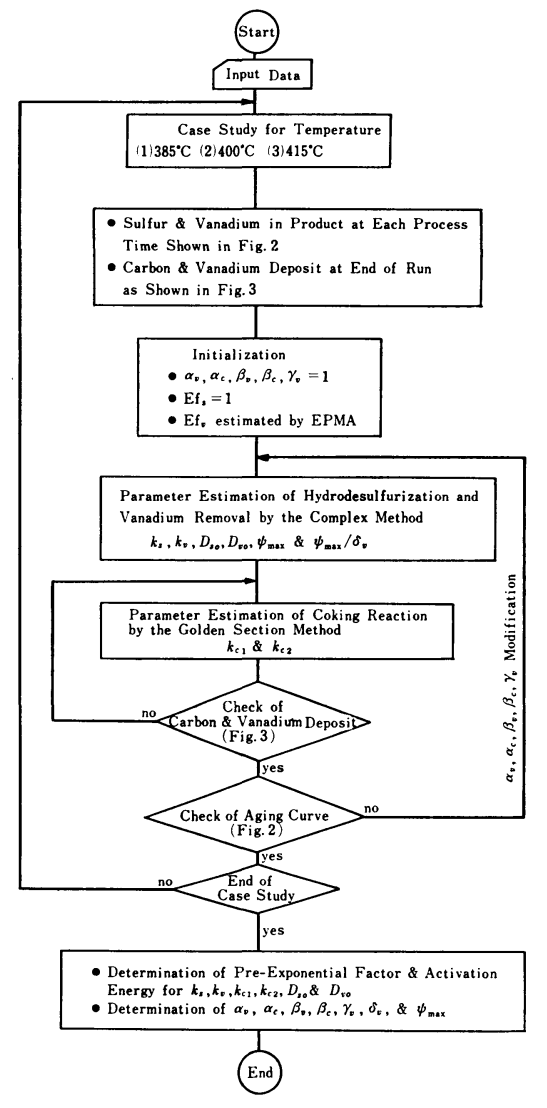

Fig. 1 Flow Scheme of Parameter Estimation

the various kinetic parameters of the simulator. Properties of the feedstocks and typical physical properties of each catalyst are summarized in Table 2 and Table 3, respectively. Isothermal HDS tests were all made under constant reaction conditions. The feed was brought together with hydrogen gas in a upflow reactor. Hydrogen gas was charged once-through. A reactor of the following dimensions was used: reactor inner diameter, $25.4 \mathrm{~mm}$; thermowell diameter in the center of the reactor, $6.35 \mathrm{~mm}$; catalyst bed volume, $400 \mathrm{~cm}^{3}$.

\subsection{Parameter Estimation}

A flow scheme of the parameter estimation in this work is shown in Fig. 1. The following brief explanation is given for case " $D$ " catalyst.

Input data such as operating conditions, properties of the feedstock and the catalyst used have been given. For the specified initial values, the effectiveness factor of vanadium was estimated with the spectrum patterns of vanadium deposits on the used catalyst measured by an electron probe micro analyzer. Parameters for desulfurization and vanadium removal were estimated for each run. The concentration of sulfur and vanadium in products was a function of the reaction rate con-

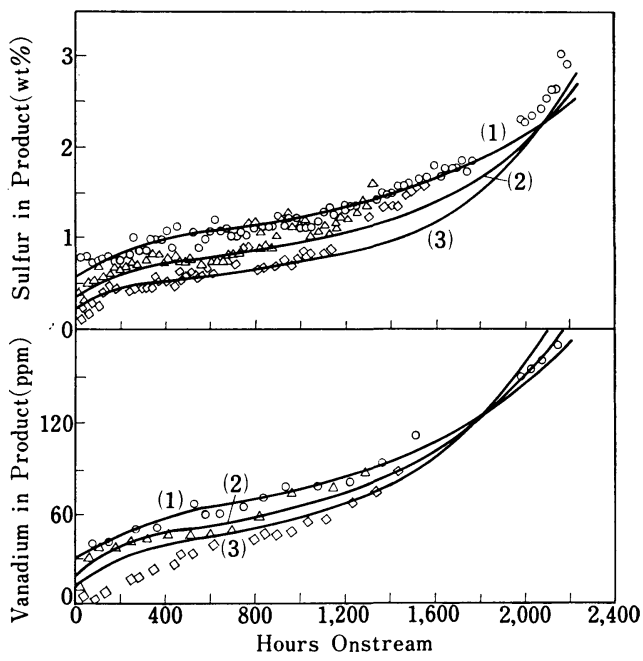

Feed : Iranian Heavy V. R. Catalyst : "D" Pressure : $140 \mathrm{~kg} / \mathrm{cm}^{2} \cdot \mathrm{G} \quad$ LHSV $: 0.46 \mathrm{hr}^{-1}$ $\mathrm{H}_{2} / \mathrm{Oil}: 1,000 \mathrm{~N} 1 / l$
Temperature : (1) $385^{\circ} \mathrm{C}$
(2) $400^{\circ} \mathrm{C}$
(3) $415^{\circ} \mathrm{C}$

Fig. 2 HDS Test Result (1)-Sulfur and Vanadium in Product

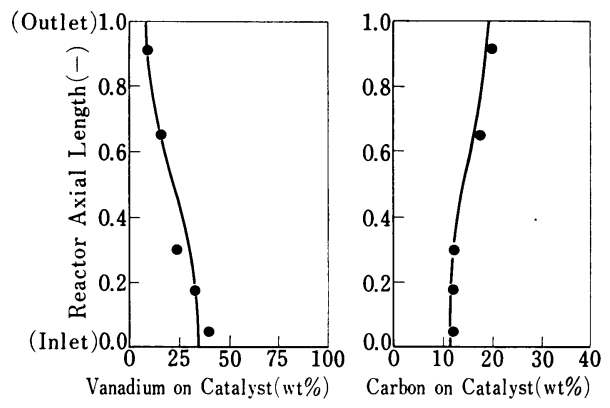

Feed : Iranian Heavy V. R. Catalyst : "D" Temperature $: 400^{\circ} \mathrm{C} \quad$ Pressure $: 140 \mathrm{~kg} / \mathrm{cm}^{2} \cdot \mathrm{G}$ LHSV : $0.46 \mathrm{hr}^{-1}$ $\mathrm{H}_{2} / \mathrm{Oil}: 1,000 \mathrm{~N} 1 / l$ Process Time : $1,360 \mathrm{hrs}$

Fig. 3 HDS Test Result (2)-Vanadium and Carbon on Catalyst

stant $k$, the effective diffusivity $D_{0}$, the dimensionless contaminants on the catalyst $\psi_{\mathrm{v}}, \psi_{\mathrm{c}}$ and $\psi_{\max }$ or $\psi_{\max } / \delta_{\mathrm{v}}$. Therefore, using the experimental data such as concentrations of sulfur and vanadium in products at any process time, and quantities of vanadium and coke on the used catalyst, parameters such as $k, D_{\text {o }}$ and $\psi_{\max }$ or $\psi_{\max } / \delta_{\mathrm{v}}$ could be estimated by used of the Complex $\operatorname{method}^{18)}$.

After the parameters for vanadium removal were determined, the coking reaction parameters $k_{\mathrm{c} 1}, k_{\mathrm{c} 2}$ were estimated until the calculated and experimentally obtained quantities of coke and vanadium on the used catalyst were in good agreement (Fig. 3). 
Table 4 Results of Parameter Estimation

\begin{tabular}{|c|c|c|}
\hline Parameter & Values for "D" Gatalyst/Iranian Heavy V.R. & $\begin{array}{l}\text { Correlation between Parameters and } \\
\text { Properties of Catalyst/Feedstock }\end{array}$ \\
\hline $\begin{array}{l}D_{\text {so }} \\
D_{\text {vo }}\end{array}$ & $\begin{array}{l}2.10 \times 10^{-6} \\
1.57 \times 10^{-6} \times \exp \left(-1.75 \times 10^{3} / R T\right)\end{array}$ & $\begin{array}{l}1.57 \times 10^{-3} \times \exp \left(-5 \times 10^{3} / R T\right) \\
4.58 \times 10^{-7} \times \exp \left(-4.32 \times 10^{7} \times P_{\mathrm{v}}^{2}\right. \\
\left.\quad+6.27 \times 10^{4} \times P_{\mathrm{v}}-13.1 \times C_{\mathrm{As}}-16.9-5 \times 10^{3} / R T\right)\end{array}$ \\
\hline $\begin{array}{l}k_{\mathrm{s}} \\
k_{\mathrm{v}} \\
k_{\mathrm{c1}} \\
k_{\mathrm{c2}}\end{array}$ & $\begin{array}{l}1.22 \times 10^{10} \times \exp \left(-31.3 \times 10^{3} / R T\right) \\
1.28 \times 10^{10} \times \exp \left(-24.2 \times 10^{3} / R T\right) \\
3.00 \times 10^{-2} \times \exp \left(-20.0 \times 10^{3} / R T\right) \\
5.35 \times 10^{-5} \times \exp \left(-10.0 \times 10^{3} / R T\right)\end{array}$ & $\begin{array}{l}k_{\mathrm{os}} * \times \exp \left(-30 \times 10^{3} / R T\right) \\
k_{\mathrm{ov}}^{*} \times \exp \left(-30 \times 10^{3} / R T\right) \\
\left(P_{\mathrm{v}} \times 10^{2}-0.0261\right) \times \exp \left(-20 \times 10^{3} / R T\right) \\
5.35 \times 10^{-3} \times \exp \left(-10 \times 10^{3} / R T\right)\end{array}$ \\
\hline $\begin{array}{l}\phi_{\max } \\
\alpha_{\mathrm{v}} / \alpha_{\mathrm{c}} \\
\beta_{\mathrm{v}} / \beta_{\mathrm{c}} \\
\gamma_{\mathrm{v}} \\
\delta_{\mathrm{v}}\end{array}$ & $\begin{array}{l}0.261(31.4 \mathrm{wt} \%) \\
1.60 / 1.80 \\
1.60 / 1.88 \\
1.60 \\
0.885\end{array}$ & $\begin{array}{l}7.4 \times 10^{-4} \times\left(3.48 \times 10^{3}-1 / P_{\mathrm{v}}\right) \times\left(0.32-C_{\mathrm{As}}\right) \\
1.6 / 1.6 \\
1.6 / 1.6 \\
1.6 \\
2.9 \times 10^{3} \times\left(2.06 \times 10^{-4}+P_{\mathrm{v}}\right) \times\left(0.407-C_{\mathrm{As}}\right)\end{array}$ \\
\hline
\end{tabular}

* $k_{\mathrm{os}} / k_{\mathrm{ov}}$ : Values obtained from Initial Activity

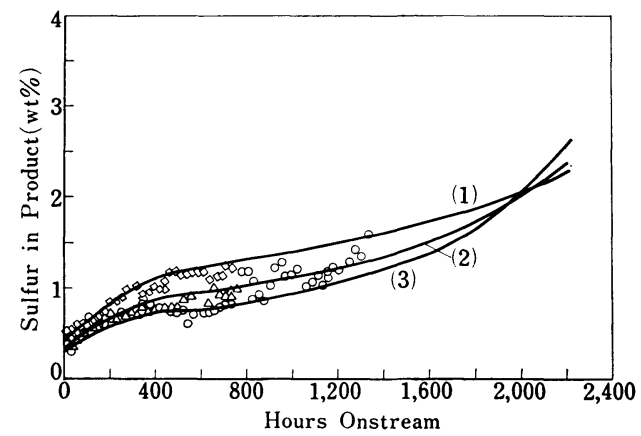

Feed : Iranian Heavy V. R. Catalyst : "D" Temperature : $400^{\circ} \mathrm{C} \quad$ LHSV $: 0.46 \mathrm{hr}^{-1}$ $\mathrm{H}_{2} / \mathrm{Oil}: 1,000 \mathrm{~N} 1 / l$

Pressure : (1) $100 \mathrm{~kg} / \mathrm{cm}^{2} \cdot \mathrm{G}$ (2) $120 \mathrm{~kg} / \mathrm{cm}^{2} \cdot \mathrm{G}$

(3) $140 \mathrm{~kg} / \mathrm{cm}^{2} \cdot \mathrm{G}$

Fig. 4 Pressure Dependency on HDS Reaction

The results of calculation were finally checked with the aging curves (Fig. 2). When the results were not satisfactory, the entire calculation was repeated by comparing with previous values of parameters $\alpha_{\mathrm{v}}, \alpha_{\mathrm{c}}, \beta_{\mathrm{v}}, \beta_{\mathrm{c}}, \gamma_{\mathrm{v}}$ for matching the catalyst deactivation behavior by trial and error.

The parameters represented by Arrhenius expression were separated by the method of least squares into pre-exponential factor and activation energy, using the results of three runs at 385,400 and $415^{\circ} \mathrm{C}$.

The calculated results of HDS of Iranian Heavy vacuum residue with " $D$ " catalyst are compared with the experimental data and illustrated in

Figs. 2 and 3. Furthermore, values of the parameters obtained are shown in Table 4. Using these values, the pressure effect on the HDS process is shown in Fig. 4.

\subsection{Correlation between Parameters and Pro- perties of Gatalyst/Feedstock}

Kinetic parameters of Iranian Heavy vacuum

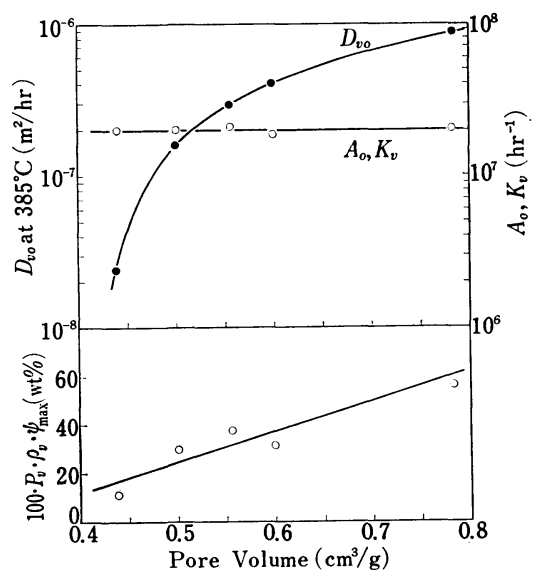

Feed : Iranian Heavy V. R.

Catalyst : "A", "B", "C", " $D$ ", and "E"

Fig. 5 Relation between Catalyst Pore Volume and Parameters

residue for other experiments in which catalysts "A", "B", "C" and "E" were used were estimated; and parameters of Khafji vacuum residue and of Iranian Heavy atmospheric residue were determined by use of the " $D$ " catalyst.

The parameters obtained were found to be significantly dependent on the properties of the catalyst and feedstock used. Typical illustrations are presented in Figs. 5 and $\mathbf{6}$. The trend shown in Figs. 5 and 6 suggests that the effective diffusivity of vanadium vary with both the catalyst pore volume and the asphaltene content. Furthermore, the result in Fig. 5 indicates that the apparent catalyst activity of vanadium removal depends on the catalyst properties which vary the effective diffusivity, and not the rate constant. As for the vanadium saturation capacity on the catalyst, the dependency on catalyst/feedstok properties is observed. The correlation between parameters and properties of catalyst/feedstock obtained is summarized 


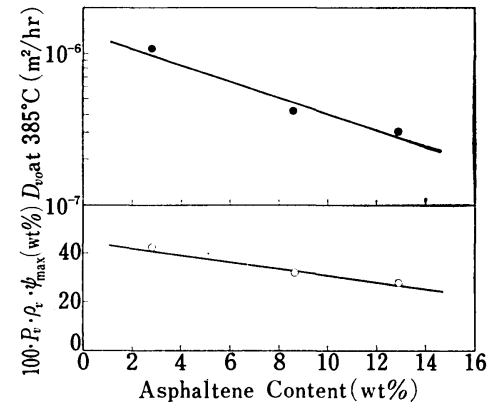

Catalyst : "D"

Feed : Iranian Heavy A. R. (S-2), Iranian Heavy V. R., Khafji V. R.

Fig. 6 Relation between Asphaltene Content of Feedstock and Parameters

\section{in Table 4.}

\section{Simulation of Bench-Scale Plant}

\subsection{Bench-Scale Plant and Operating Pro- cedure}

The applicability of HDS simulator was studied by use of the bench-scale plant data, which were obtained from the runs to produce $0.8 \mathrm{wt} \%$ sulfur fuel oil from Iranian Heavy vacuum residue. Two bench-scale plants used were isothermal and upflow type reactors. One of the plants was a fixedbed plant and the other was a moving-bed simulator using fixed-bed reactors.

Dimensions of the fixed-bed plant were as follows: inner diameter, $25.4 \mathrm{~mm}$; thermowell diameter in the center of the reactor, $6.35 \mathrm{~mm}$; catalyst bed volume; $250 \mathrm{~cm}^{3}$.

The moving-bed simulator system included seven reactors, which were serially connected. A sche- matic flow diagram of the system is illustrated in Fig. 7. Five reactors are onstream normally and the other two are offstream for catalyst change. Each reactor had the same dimensions as those of the fixed-bed plant. The total catalyst bed volume was $450 \mathrm{~cm}^{3}\left(90 \mathrm{~cm}^{3} \times 5\right.$ reactors $)$. The maximum operating temperature was $400^{\circ} \mathrm{C}$ as shown in Fig. 9. After start-up the temperature was gradually raised in order to maintain the sulfur content in the products to $0.8 \mathrm{wt} \%$ to prevent losses in catalyst activity with time. When the maximum temperature was reached, it was kept constant. When the sulfur in the products exceeded $1.0 \mathrm{wt} \%$, the first reactor was disconnected from the others, and a standby reactor was connected at the outlet of the reactor system. After sulfur in the products decreased to $0.7 \mathrm{wt} \%$, the sulfur level was permitted to increase with time. And whenever sulfur in the products exceeded $1.0 \mathrm{wt} \%$, the same procedure for reactor exchange was carried out. In this model operation, thus, the sulfur levels changed from approximately 0.6 to $1.0 \mathrm{wt} \%$, or to about $0.8 \mathrm{wt} \%$ on average.

\subsection{Simulation of Fixed-Bed Reactor and Moving-Bed Simulator}

The method used for calculation of simulation is presented in the appendix.

Fig. 8 shows simulation for the fixed-bed reactor. The input data were: kinetic parameters, properties of catalyst and feedstock, and reaction conditions. The simulation procedure was such that when sulfur in the products exceeded $0.83 \mathrm{wt} \%$, the temperature was raised in steps of $2^{\circ} \mathrm{C}$. The

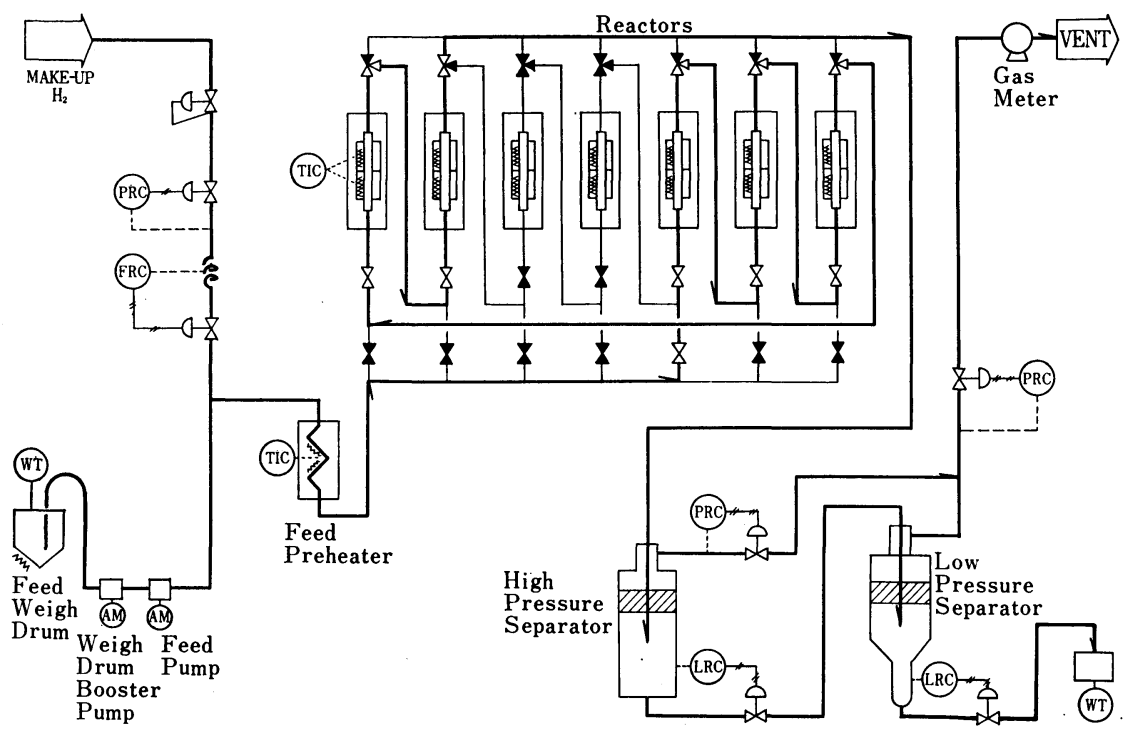

Fig. 7 Schematic Flow Diagram of Moving-Bed Bench Scale Simulator 


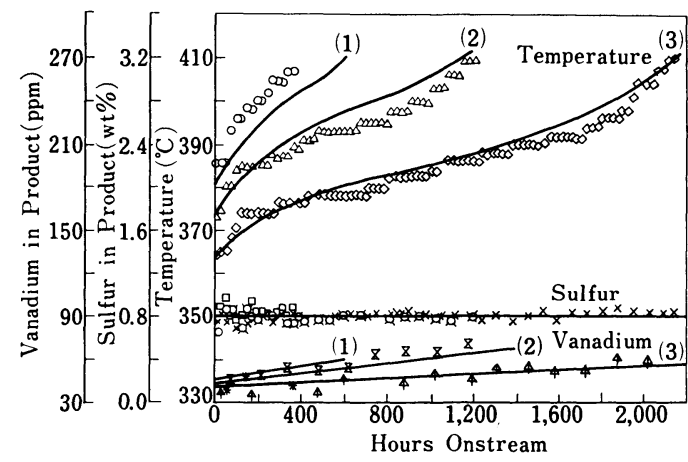

Catalyst : "D" Pressure : $140 \mathrm{~kg} / \mathrm{cm}^{2} \cdot \mathrm{G}$ $\mathrm{H}_{2} / \mathrm{Oil}: 1,000 \mathrm{~N} 1 / l$
LHSV : (1) $0.60 \mathrm{hr}^{-1}$
(2) $0.46 \mathrm{hr}^{-1}$
(3) $0.30 \mathrm{hr}^{-1}$

Fig. 8 HDS of Iranian Heavy V. R. in a Fixed-Bed Bench Scale Plant

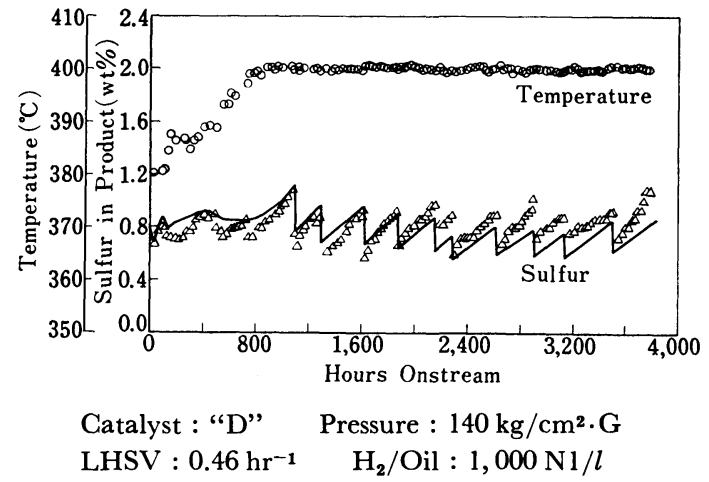

Fig. 9 HDS of Iranian Heavy V. R. in a Moving-Bed Bench Scale Simulator

aging curves and the vanadium content in the products were calculated. Fig. 9 shows the results of simulation in the moving-bed simulator. The input data were the same as those in the fixed-bed. The simulation procedure for this case was as follows: before the first reactor was exchanged, sulfur in the products was calculated at the given temperature; after the exchange, the sulfur content was calculated at the constant temperature by using the distribution of catalyst activity in the system, in which the catalyst in the reactor connected at the outlet was fresh.

A distinctive feature of the simulation shown in Fig. 8 appeared in three aging curves, that was the effect of changing the liquid hourly space velocity (LHSV) on catalyst life. If catalyst life cycle were dependent only on metal contamination, the life cycle at 0.3 LHSV would be approximately two times as long as the one at 0.6 LHSV. However, since the catalyst life at 0.3 LHSV was much longer than that expected, it was clear that deactivation caused by coking was not negligible.

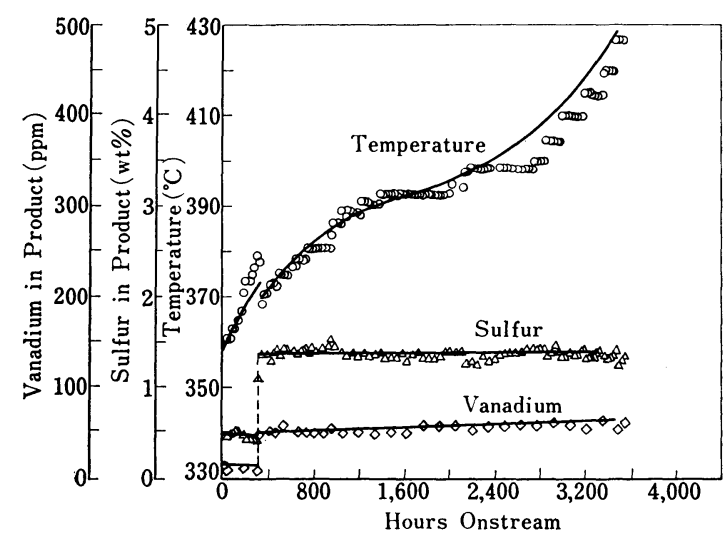

Catalyst : "C" Pressure : $112 \mathrm{~kg} / \mathrm{cm}^{2} \cdot \mathrm{G}$ LHSV : 0.32/1.5 $\mathrm{hr}^{-1} \quad \mathrm{H}_{2} /$ Oil : $1,000 \mathrm{~N} 1 / l$

Fig. 10 HDS Simulation by Use of a Parameter Correlation-Iranian Heavy A. R. (S-2)

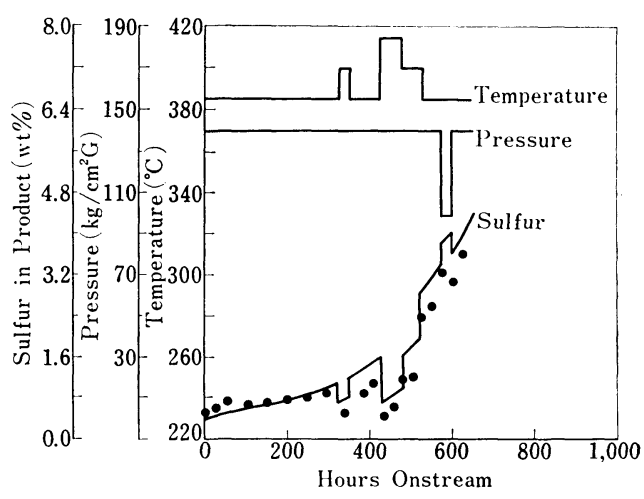

Catalyst : "D" LHSV : $0.46 \mathrm{hr}^{-1}$ $\mathrm{H}_{2} / \mathrm{Oil}: 1,000 \mathrm{Nl} / l$

Fig. 11 HDS Simulation by Use of a Parameter Correlation-Boscan Crude

On the other hand, the simulation shown in Fig. 9 indicated that sulfur in the products increased sharply not gradually after the reactor exchange. It was considered that deactivation was due mainly to coke deposits, and not to metal contamination, because only about $1 \mathrm{wt} \%$ of vanadium was deposited on the catalyst during 200 or 300 hours after the reactor exchange.

\subsection{Simulation by Use of Parameter Cor- relation}

It frequently becomes necessary to estimate reactivity and catalyst life of any feedstock by shortterm HDS tests. However, such kinetic parameters as vanadium capacity and coking rate constant which affect catalyst deactivation behavior cannot be determined only by such shortterm HDS tests. For that purpose, the correlation already obtained between the HDS simulation parameters and the properties of catalyst/feedstock 
are practical and useful. Two examples of such use are illustrated in Figs. 10 and 11. The properties of the feedstocks and the catalysts used are shown in Tables 2 and $\mathbf{3}$, respectively.

The bench-scale plant aging runs shown in Fig. 10 were made under the following conditions: the level of sulfur in the products kept at $0.4 \mathrm{wt} \%$ at $0.32 \mathrm{LHSV}$ for 300 hours; the level of sulfur kept at $1.4 \mathrm{wt} \%$ at 1.5 LHSV after 300 hours. The run shown in Fig. 11 was made at constant LHSV but with variable temperature and pressure. Simulation kinetic parameters for Figs. 10 and 11 were estimated by use of the correlation summarized in Table 4 except for the pre-exponential factors of sulfur and vanadium removal. These factors were repeatedly determined to get a good agreement between results of calculation and experimental data of sulfur and vanadium in the products at start of the run. The aging curves and vanadium in the products shown in Fig. 10 were simulated by the same procedure as in Fig. 8. The variation in the levels of sulfur in the products shown in Fig. 11 was simulated by using actual reaction conditions.

The use of the parameters thus predicted enables us to get an accurate estimate of the cycle length or catalyst consumption.

\section{Conclusion}

Hydrotreating petroleum stocks of high metal contents, such as Iranian Heavy vacuum residue and Venezuelan heavy crude, will be associated with more severe fouling of the HDS catalysts. The axial distribution of catalyst activity in the reactor of the MDS Process, in which the catalyst is continuously charged and discharged, was considered. To represent the fouling process, an improved model, which included both the interaction of coking reaction and vanadium removal and the pore-plugging was developed.

A good agreement with the bench-scale plant data was obtained with the HDS simulator based on the above deactivation model. The simulator was useful and practical for predicting the reactor performance in the fixed-bed and moving-bed systems.

\section{Appendix}

The calculation scheme of the program is shown in Fig. 12. The reactor length and the process time are divided into $i$ and $j$, respectively, for the finite difference approach in the program.

First of all, the catalyst is defined as a fresh

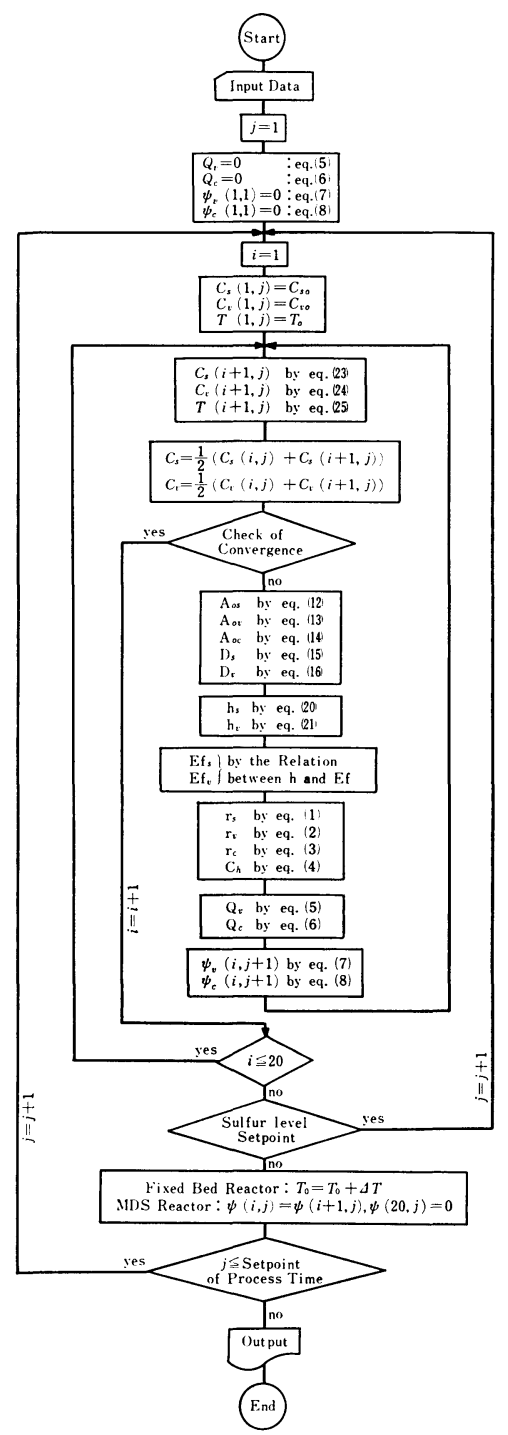

Fig. 12 Flow Chart of the Program Used for Residue HDS Calculation

catalyst at start of run $j=1$ according to Eqs. (5) to (8). After setting concentration of sulfur/vanadium and reaction temperature to those of the feed, calculation starts in the first stage of reactor $i=1$ using Eqs. (23) to (25), which are solved using the Newton-Rapson method. Thiele-moduli can be determined from the values of the surface area and effective diffusion coefficient defined in Eqs. (12) to (16). The effectiveness factors can be given from the relationship between Thielemodulus and effectiveness factor. Calculation at this stage of the reactor should be repeated according to Eqs. (1), (2), (4) and (23) to (25) until the values of the concentration at the outside surface of the pellet converge. At the same time, the amounts of vanadium and coke on the catalyst will have already been calculated. 
After the calculation of concentration and temperature along the reactor axis is complete, the program proceeds to the next step of process time $j+1$ using the amounts of vanadium and coke on the catalyst which have already been calculated in the prior step of process time $j$.

If the concentration of sulfur is above the level set, the reaction temperature is raised or a fresh catalyst is charged with the same amount of used catalyst drawn off.

The HDS reaction characteristics in the reactor such as concentrations of sulfur and vanadium, quantities of vanadium and coke deposits, and activity of the catalyst at each stage of the reactor and in each process period are described.

(Presented at AIChE 86th National Meeting, Houston, Texas, April, 1979)

\section{Nomenclature}

$A_{\mathrm{o}}=$ surface area of fresh catalyst, $\mathrm{m}^{2} / \mathrm{kg}$

$A_{\mathrm{o}}{ }^{\prime}=$ remaining surface area of catalyst under use, $\mathrm{m}^{2} / \mathrm{kg}$

$A_{\mathrm{oc}}=$ effective surface area of catalyst under use for coke deposition expressed in Eq. (14), $\mathrm{m}^{2} / \mathrm{kg}$

$A_{\text {os }}=$ effective surface area of catalyst under use for desulfurization reaction expressed in Eq. (12), $\mathrm{m}^{2} / \mathrm{kg}$

$A_{\mathrm{ov}}=$ effective surface area of catalyst under use for vanadium removal reaction expressed in Eq. (13), $\mathrm{m}^{2} / \mathrm{kg}$

$C_{\mathrm{h}}=$ concentration of hydrogen, $\mathrm{kg} / \mathrm{kg}$

$C_{\mathrm{p}}=$ heat capacity, $\mathrm{kcal} / \mathrm{kg} \cdot{ }^{\circ} \mathrm{G}$

$C_{\mathrm{As}}=$ concentration of asphaltene in feed oil, $\mathrm{kg} / \mathrm{kg}$

$C_{\mathrm{s}}=$ concentration of sulfur, $\mathrm{kg} / \mathrm{kg}$

$C_{\mathrm{so}}=$ concentration of sulfur in feed oil, $\mathrm{kg} / \mathrm{kg}$

$C_{\mathrm{v}}=$ concentration of vanadium, $\mathrm{kg} / \mathrm{kg}$

$C_{\mathrm{vo}}=$ concentration of vanadium in feed oil, $\mathrm{kg} / \mathrm{kg}$

$D_{\mathrm{s}}=$ effective diffusivity of sulfur, $\mathrm{m}^{2} / \mathrm{hr}$

$D_{\text {so }}=$ initial effective diffusivity of sulfur, $\mathrm{m}^{2} / \mathrm{hr}$

$D_{\mathrm{v}}=$ effective diffusivity of vanadium, $\mathrm{m}^{2} / \mathrm{hr}$

$D_{\text {vo }}=$ initial effective diffusivity of vanadium, $\mathrm{m}^{2} / \mathrm{hr}$

$E_{\mathrm{f}}=$ effectiveness factor

$h=$ Thiele-modulus

$k=$ intrinsic rate constant, $\mathrm{kg} / \mathrm{m}^{2} \cdot \mathrm{hr}$

$k_{\mathrm{o}}=$ pre-exponential factor in rate constant, $\mathrm{kg} /$ $\mathrm{m}^{2} \cdot \mathrm{hr}$

$P=$ pressure, $\mathrm{kg} / \mathrm{cm}^{2} \cdot \mathrm{G}$

$P_{\mathrm{v}}=$ pore volume of fresh catalyst, $\mathrm{m}^{3} / \mathrm{kg}$

$P_{\mathrm{v}}{ }^{\prime}=$ remaining pore volume of catalyst under use, $\mathrm{m}^{3} / \mathrm{kg}$

$Q=$ quantity of contaminant on catalyst, wt $\%$

$q=$ quantity of contaminant on catalyst, $\mathrm{kg} / \mathrm{m}^{3}$

$R=$ gas constant, $\mathrm{cal} / \mathrm{g} \cdot \mathrm{mol} \cdot{ }^{\circ} \mathrm{K}$

$r=$ distance from pellet center, $\mathrm{m}$

$r_{\mathrm{o}}=$ equivalent radius of catalyst pellet, $\mathrm{m}$

$r_{\mathrm{c}}=$ coking rate, $\mathrm{kg} / \mathrm{m}^{3} \cdot \mathrm{hr}$ $r_{\mathrm{s}}=$ rate of desulfurization, $\mathrm{kg} / \mathrm{m}^{3} \cdot \mathrm{hr}$

$r_{\mathrm{v}}=$ rate of vanadium removal, $\mathrm{kg} / \mathrm{m}^{3} \cdot \mathrm{hr}$

$T=$ temperature, ${ }^{\circ} \mathrm{K}$

$U=$ mass flow rate, $\mathrm{kg} / \mathrm{m}^{2} \cdot \mathrm{hr}$

$Z=$ distance from reactor inlet, $\mathrm{m}$

\section{Greek Letters}

$\alpha=$ parameter expressed in Eq. (12)

$\beta=$ parameter expressed in Eq. (13)

$\gamma=$ parameter expressed in Eq. (14)

$\delta=$ parameter expressed in Eq. (15)

$-\Delta H_{\mathrm{s}}=$ heat of reaction, $\mathrm{kcal} / \mathrm{kg} \cdot \mathrm{sulfur}$ removed

$\varepsilon=$ catalyst charge volume, $\mathrm{m}^{3} / \mathrm{m}^{3}$

$\eta=$ dimensionless distance from pellet center

$\theta=$ process time, $\mathrm{hr}$

$\rho=$ density, $\mathrm{kg} / \mathrm{m}^{3}$

$\phi=$ dimensionless concentration

$\phi=$ dimensionless quantity of contaminant on catalyst

$\psi_{\max }=$ dimensionless vanadium capacity on catalyst

\section{Subscripts}

$$
\begin{aligned}
\mathrm{c} & =\text { coke } \\
\mathrm{cat} & =\text { catalyst } \\
\mathrm{g} & =\text { gas phase } \\
\mathrm{h} & =\text { hydrogen } \\
\mathrm{l} & =\text { liquid phase } \\
\mathrm{s} & =\text { sulfur } \\
\text { oil } & =\text { oil phase } \\
\mathrm{v} & =\text { vanadium } \\
\mathrm{c} 1 & =\text { coke formation } \\
\mathrm{c} 2 & =\text { coke hydrogenation }
\end{aligned}
$$

\section{References}

1) Beuther, H., Schmid, B. K., Proc. 6th World Petrol. Congr., Section 3, 297 (1963).

2) Wakao, N., Egi, K., Kagaku Kogaku, 34, 1239 (1970).

3) Ozaki, H., Satomi, Y., Hisamitsu, T., Paper presented at 9th World Petrol. Congr., PD 18 (4) (1975).

4) Kosugi, M., Yoshizawa, T., J. Japan Petrol. Inst., 21, 199 (1978).

5) Shah, Y. T., Paraskos, J. A., Ind. Eng. Chem., Process Des. Develop., 14, 368 (1975).

6) de Bruijn, A., Proc. 6th Int. Congr. Cat., 951 (1977).

7) Mosby, J. F., Hoekstra, G. B., Kleinhenz, T. A., Sroka, J. M., Proc. 38th Midyear Meeting of the API Div. of Refining, 488 (1973).

8) Spry, J. G., Sawyer, W. H., Paper Presented at AIChE 68th Annual Meeting, Los Angeles, Calif., Nov. (1975).

9) Inoguchi, M., Kagaya, H., Daigo, K., Sakurada, S., Satomi, Y., Inaba, K., Tate, K., Nishiyama, R., Onishi, S., Nagai, T., Bull. Japan Petrol. Inst., 13, 153 (1971).

10) Wheeler, A., "Catalysis", Vol. 2, (1955), Reinhold, New York.

11) Wheeler, A., Robell, J. A., J. Catal., 13, 299 (1969).

12) Masamune, S., Smith, J. M., AIChE J., 12, 384 (1966).

13) Newson, E., Ind. Eng. Chem., Process Des. Develop., 
14, 27 (1975).

14) Parkin, E. S., Paraskos, J. A., Frayer, J. A., Paper Presented at AIChE 74th National Meeting, New Orleans, Lousiana, March (1973).

15) Tamaki, A., J. Japan Petrol. Inst., 17, 917 (1974).

16) Khang. S. J., Levenspiel, O., Ind. Eng. Chem., Fundam., 12, 185 (1973).

17) Carberry, J. J., Gorring, R. L., J. Catal., 5, 529 (1966).

18) Komatsu, S., Umeda, T., "Process System Design,"
(1973), Kogyo Chosakai, Tokyo, Japan.

19) Kato, J. et al., J. Chem. Soc. of Japan, Ind. Chem. Sect., 74, 1047 (1971).

20) Inoguchi, M., Inaba, K., Satomi, Y., Mizutori, T., Sakurada, S., Kagaya, H., Nishiyama, R., Tate, K., Onishi, S., Nagai, T., Bull. Japan Petrol. Inst., 13, 11 (1971).

21) Lapidus, L., "Digital Computation for Chemical Engineers," (1962), McGraw-Hill.

要 旨

\section{触媒劣化モデルに基づく残油脱硫反応のシミュレーション}

児玉 省二*1), 新田 治彦*2), 高塚 透*1), 横山 徹*1)

残油の水素化脱硫触媒の寿命は，触媒上一の炭素質のたい積 と金属のたい積により制限を受ける ${ }^{13)}$ 。本研究では，これらに よる触媒劣化と反応速度の組み合わせにより残油の水素化脱硫 反応の実験結果を統一的に説明することを目的としたシミュレ 一タを作成した。

触媒の劣化には, 活性表面の減少と反応物の有効桩散係数の 減少によるモデルを適用した。高度に劣化した触媒の分析結果 (Table 1) を考虑して，炭素質の生成反応と脱金属反応が相 互に影響をおよぼし合うモデルを設定した。

シミュレータの定数を決定するために，3 種の残油（Table

2) 括よび 5 種の触媒（Table 3）を用いて脱硫反応のテスト

*1) 千代田化工建設株式会社総合研究所 (221 横浜市神奈川 区守屋町 3-13)

*2）千代田化工建設株式会社石油エンジニアリング部（230 横浜市鶴見区鶴見町 1580)
を行った。反応は通常の高圧流通系固定床式反応装置を上昇流 で使用して行い，各ランは一定の反応条件に保った。実験デー タから得られたシミュレータの定数をイラニアンヘビー減圧残 油/触媒Dについて Table 4 に示し, この定数を用いた計算 結果と実験結果を Figs. 2〜4 に示した。

イラニアンービー減圧残油から, 硫黄濃度 $0.8 \mathrm{wt} \%$ の生成 油を得るベンチプラントの実験データを，固定床式および模擬 移動床式についてそれぞれ Fig. 8 および Fig. 9 に示し, シ ミュレーション結果と実験結果が一致することを確認した。

種々の実験により得られたシミュレータの定数は, 触媒と原 料油の物性に大きく依存している (Figs. 5, 6)。

これらの相関（Table 4） と，初期活性データを利用したシ ミュレーション結果は, 温度, 圧力, 液空間速度などの反応条 件が異なる残油の水素化脱硫反応に適用できた (Figs. 10,11)。

\section{Keywords}

Hydrodesulfurization, Residual oil, Deactivation, Simulation 